\title{
Evaluation of the survival of patients with cirrhosis of viral etiology B / C in 3 hospitals of Kinshasa in the Democratic Republic of Congo
}

Aliocha Nkodila ( $\square$ nkodilaaliocha@gmail.com )

Universite de Kinshasa https://orcid.org/0000-0002-1403-8451

Charles Mbendi

Universite de Kinshasa

Vanessa Malumba

"University of kinshasa

Hervé Alex Tukadila

University of Kinshasa

Grace Kisalambote

Universite de Kinshasa

Clovis Kumbu

Universite de Kinshasa

Pascal Tshiamala

Ngaliema clinic

Antoine Tshimpi

Universite de Kinshasa

Sébastien Mbendi

Universite de Kinshasa

Moustapha Moulay Ennaji

university of casablanca

Benjamin Longo

University of Kinshasa

Research article

Keywords: Survival, cirrhosis, HBV, HCV, DR Congo

Posted Date: March 20th, 2020

DOI: https://doi.org/10.21203/rs.3.rs-17904/v1 
License: (c) (i) This work is licensed under a Creative Commons Attribution 4.0 International License. Read Full License 


\section{Abstract}

Background and objective : The causes of declining survival in cirrhotic patients are dominated by complications in developing countries. But data on survival among cirrhotics in Sub-Saharan Africa are sketchy. The general objective was to assess the survival and predictors of mortality in patients with viral cirrhosis of the liver in 3 hospitals in the Democratic Republic of Congo.

Methods: A historic cohort study from 2009 to December 2018. Patients were recruited and followed up at the Ngaliema Clinic, CUK and HPGRK for 10 years. Death was the endpoint and patients lost to followup were censored. The Kaplan Méier curves made it possible to describe the survival of children at the threshold of $p<0.05$.

Results : One hundred and four, 124 were male (75.6\%), mean age $50.1 \pm 16.1$ years, $54.9 \% \mathrm{HBV}$ viral etiology and $18.9 \%$ HBV-HCV co-infection were included. $37.8 \%$ cirrhotic had died. The probability of survival for cirrhotic patients at the start of follow-up was $81.7 \%, 69.5 \%, 62.2 \%, 62.2 \%$ and $62.2 \%$, respectively, at 1 year, 2 years, 3 years, 4 years and 10 years. The predictors of mortality were age $\geq 60$ years, hepatocellular carcinoma, encephalopathy, Child Pugh class B and C and low $\mathrm{Hb}$.

Conclusion: complications in cirrhotics are the factors of poor prognosis for the survival of patients in this cohort. Early detection of cirrhosis increases the survival of cirrhotic patients.

\section{Introduction}

The conditions for admission to hospital for populations at high risk of mortality, such as patients with malignant hemopathy, a chronic disease have been widely studied, there are few specific data for the cirrhotic patient [1].

The proposal to admit a cirrhotic patient into hospital frequently raises reluctance on the part of clinicians given the high probability of death attributed a priori to these patients. In fact, several serious complications: digestive hemorrhage, encephalopathy, bacterial infections or acute renal failure can occur in patients with cirrhosis [2].

In addition, given the alterations in the immune system on the one hand and the cardio-circulatory system on the other hand, the risk of multiple organ failure is particularly high in these patients. Several studies have shown that cirrhosis is an independent factor of mortality during clinical pathologies. It is an independent predictor of death in patients hospitalized for respiratory failure $[3,4-8]$.

To determine the risk factors associated with the mortality of these patients, multiple studies have analyzed the relevance of numerous scores. The Child-Pugh score has been extensively studied, as have "general" clinical severity scores such as the Simplified Severity Index (IGS II) or APACHE II. These scores are correlated with the mortality of patients, but none can be used to identify with sufficient reliability patients before or not to be admitted to hospital [9]. Hence the need to look for these factors by studying 
survival. The objective of this study is to assess the survival and predictors of mortality in patients with viral cirrhosis of the liver in 3 hospitals in the city of Kinshasa in the Democratic Republic of Congo.

\section{Patients And Methods}

This was a historical cohort study from 2009 to December 2018. Patients were recruited and monitored at the Ngaliema Clinic, the University Clinics and the Provincial General Reference Hospital in Kinshasa for 10 years.

The population studied consisted of all patients with cirrhosis of the liver of viral etiology B and / or C recruited into the cohort and followed in the 3 hospitals mentioned until 2018. The primary outcome was death and viral serology. Patients lost to follow-up were censored.

Inclusion criteria: any patient over the age of 15 , diagnosed with cirrhotic virus etiology B and / or C, having a file containing all the elements necessary for this study.

Patients who had not performed viral serology, those with negative serology and those with an unusable record were not included in the study.

The systematic review of patient files made it possible to obtain, from an ad hoc survey form, the information essential for this study. The diagnosis of cirrhosis was made on a set of clinical and paraclinical arguments: hepatocellular insufficiency defined by jaundice and portal hypertension by the presence of abdominal collateral venous circulation, esophageal varices and morphological modifications of the liver to type of hepatic or micronodular liver dysmorphia on abdominal ultrasound.

The complications sought were: ascites defined by abdominal bloating associated with the unfolding of the umbilicus on physical examination or visualization on ultrasound, upper gastrointestinal hemorrhage by rupture of the esophageal varices externalized in the form of hematemesis and / or melena, hepatocellular carcinoma associated or not with one or more hepatic nodules and / or portal thrombosis associated with morphological modifications of the liver on abdominal ultrasound.

The biological examinations carried out were as follows: transaminases, blood count, blood sugar, uremia, creatinine and the serology of viral hepatitis. Digestive endoscopy, non-invasive fibrosis tests, and $\mathrm{PBH}$ were not available.

The progress of the patients was assessed by the stage of cirrhosis described by the Child Pugh classification. Any patient with a score between 5-6 was class $A$, the patient with a score between 7-9 was class $B$ and class $C$ included any patient with a score between 10 and 15 [10].

Statistical analyzes

The data was entered and encoded using Excel 2010 software. Data analysis was performed using SPSS version 22 software. 
Descriptive statistics were presented in the form of more or less standard deviation means, percentages and confidence intervals $(95 \% \mathrm{Cl})$ as appropriate.

The comparisons between the groups were made as appropriate, using, respectively, the Student $t$ test (normally distributed variables) for the continuous (quantitative) variables; the chi-square test or Fisher's exact test for categorical (qualitative) variables.

Kaplan Meier's method described survival from the first day of hospitalization until death (complete data) to the end of the study (censored data). Patients lost to follow-up $(n=32)$ or alive at the end of the study were censored. The Log-rank test was used to compare the survival curves. The Cox regression looked for independent predictors of mortality. A value of $p<0.05$ was considered as the threshold of statistical significance.

Patient recruitment was carried out on the basis of free and informed consent in accordance with the Helsinki recommendations. The study protocol was submitted for analysis and approval to the Ethics Committee of the School of Public Health at the University of Kinshasa. The approval number received is ESP / CE 037/2017. The confidentiality and ethical rules were respected by the members of the research team when collecting the data.

\section{Results}

Death rate in the cohort

Out of a total of 164 cirrhotics recruited from this cohort, $62(37.8 \%)$ had died and $102(62.2 \%)$ had survived.

General characteristics of the study population

Of 164 cirrhotics followed during the study period, $75.6 \%$ were men (sex ratio $3 \mathrm{H}$ : $1 \mathrm{~F}$ ); their average age was $50.1 \pm 16.1$ years, the majority in class A of Child Pugh (37.8\%) with a frequency of history of alcohol consumption (65.9\%), hypertension (18.3\%) and Diabetes mellitus (15.9\%). HBV was more common with $54.9 \%$ viral etiology and $18.9 \%$ HBV-HCV co-infection was present. Ascites and jaundice were the most common complications. Comparing with the survivor, we note that the deceased cirrhotics were significantly men $(p<0.001)$, older $(p=0.001)$; had a significantly high frequency of Child C Pugh class $C$ $(p<0.001)$, hypertension, ascites, digestive hemorrhage, $\mathrm{CHC}$, jaundice and hepatic encephalopathy (Table 1).

Biological characteristics

The mean and median values of the biological characteristics of cirrhotics are pathological. When compared to survivors, deceased cirrhotics had significantly higher medians of albumin, BT, BD and ygt 
(Table 2).

Overall survival of cirrhotics

The probability of survival for cirrhotic patients at the start of follow-up was $81.7 \%, 69.5 \%, 62.2 \%, 62.2 \%$ and $62.2 \%$, respectively, at 1 year, 2 years, 3 years, 4 years and 10 years. The median survival of cirrhotic patients was 15 (13.0-16.0) months (Figure 1).

\section{Survival based on gastrointestinal bleeding}

Cirrhotics with no digestive hemorrhage tended to have better survival compared to those with gastrointestinal bleeding, with a statistically significant difference $(p<0.001)$ (Figure 2$)$.

\section{Survival by stage of Child Pugh}

The comparison of the survival curves of cirrhotics, according to Child Pugh stage, had shown that survival was significantly $(p<0.001)$ shorter in class $C$ and B cirrhotics than in class A (Figure 3 )

\section{Survival according to the presence or not of hepatocarcinoma}

The comparison of the survival curves of cirrhotics according to the presence or not of the hepatocarcinoma shows a statistically significant difference $(p<0.001)$; the presence of hepatocarcimone during follow-up with cirrhotics reduces the survival of these patients (Figure 4).

\section{Survival based on hepatic encephalopathy}

The comparison of the survival curves of cirrhotic patients according to the presence of hepatic encephalopathy or not shows a highly significant difference $(p=0.005)$. The presence of hepatic encephalopathy seems to negatively influence the survival of cirrhotic during follow-up (Figure 5).

\section{Predictors of mortality in cirrhotic patients}

In multivariate analysis, after adjustment, encephalopathy (HRa: 3.62; 95\% Cl: 1.48-8.88), hepatocarcinoma (HRa: 3.48; 95\% Cl: 1.35-8.99) , Child Pugh class B and C (HRa: 7.14; 95\% Cl: 1.17-9.54) and (HRa: 8.79; 95\% Cl: 2.78-10.36), were independently associated and significantly at risk of death for cirrhotic patients (Table 3).

\section{Discussion}

Cirrhosis remains a major cause of death in several regions of the world [11] including in the DRC. In our study, the mortality rate recorded during follow-up was $37.8 \%$. The probability of survival for cirrhotic patients at the start of follow-up was $81.7 \%, 69.5 \%, 62.2 \%, 62.2 \%$ and $62.2 \%$, respectively, at 1 year, 2 years, 3 years, 4 years and 10 years. The median survival of PLWHIV was 15 (13.0-16.0) months. According to studies, 10-year survival ranges from 21-99\% [12-15]. Our results join those of Amico et al, 
who were interested in cirrhosis of different etiologies, compensated and decompensated, since they found a 10 -year survival of $40 \%$ and a mortality rate of $39.9 \%$ [13].

The present study, describing survival according to the Kaplan Meier method, has shown that several factors have an impact on the survival of cirrhotic patients. As expected, the presence of HD, encephalopathy, hepatocellular carcinoma and Child Pugh stage significantly influence the survival of cirrhotics. Several studies have already shown the impact of these factors, such as the study by Gentilini et al [16]. According to these authors, these factors are the basis of multiple organ failure during cirrhosis.

After adjusting for clinical characteristics, only encephalopathy, hepatocellular carcinoma and Child Pugh stages $B$ and $C$ had a higher risk of independently reducing the survival of cirrhotic patients in this series. This trend was already reported in 2008 by Attia KA et al [17] and in 2005 to by Cholongitas E et al [18]. These results are contrary to the results of Gildea TR et al, who found oligo-anuria as predictors of mortality in cirrhotics (OR 22; 95\% Cl [2.4-99], $\mathrm{p}=0.006$ ), a MELD score $>20$ (OR 3.2; 95\% Cl [1.3-8], $\mathrm{p}=$ 0.01 ), nosocomial infection (OR 4.5; $95 \% \mathrm{Cl}[1.7-11.8], \mathrm{p}=0.002$ ) and the IGS II score > 39 (OR 3.25; IC95\% [1.3-8.3], $\mathrm{p}<0.0001)$ [19]. This difference could be explained by the methodology used in his study which is different from ours. It should be noted that late management in our environment is an important factor to take into account in the survival of cirrhotics. The low socioeconomic level of the patients does not allow early consultation of these patients in the best health facilities, allowing patients to go to small centers where the management of cirrhosis is not correct.

This study has certain limitations. The study is first of all a historical cohort, so we cannot exclude the presence of unmeasured confusion. Then our study was carried out in 3 centers and the sample size is relatively small. Therefore, our results may not be generalized across the country. Its strength is that it is the first of its kind to describe the survival of cirrhotics in the middle of Kinshasa.

\section{Conclusion}

The results of our study showed that cirrhotics with gastrointestinal hemorrhage, hepatic encephalopathy and Child Pugh class $\mathrm{C}$ and $\mathrm{B}$ had reduced survival. These factors were therefore independently associated with mortality.

\section{Declarations}

\section{Conflict of interest}

The authors declare no conflict of interest.

\section{Authors' contribution}

Charles Mbendi and Aliocha Nkodila designed and wrote the article. Vanessa Mulamba, Hervé Alex Tukadila, Clovis Kumbu and Grace Kisalambote carried out the survey. Aliocha Nkodila analyzed the data; 
Benjamin Longo, Moustapha Moulay, Antoine Tshimpi, Pascal Tshiamala and Sébastien Mbendi coordinated the study. All authors approved the final version and revised the manuscript.

\section{Acknowledgments}

We thank all those who from far or near agreed to participate in this study; all the investigators, the cirrhotic patients who agreed to carry out the analyzes on hepatitis $B$ and $C$ that the hospitals who willingly approved and supported within them the data collection.

\section{References}

1.

Monchi M, Bellenfant F, Cariou A, Joly LM, Thebert D, Laurent I, et al. Early predictive factors of survival in the acute respiratory distress syndrome. Am J RespirCrit Care Med. 1998;158:1076-81.

2.

Zauner CA, Apsner RC, Kranz A, Kramer L, Madl C, Schneider B, et al. Outcome prediction for patients with cirrhosis of the liver in a medical ICU: a comparison of the APACHE scores and liver-specific scoring systems. Intensive Care Med 1996; 22 : 559 - 63.

3.

Castera L, Pauwels A, Levy VG. Indicateurs pronostiques chez les malades atteints de cirrhose admis en réanimation. Gastroenterol Clin Biol. 1996;20:263-8.

4.

Signh N, Gayowski T, Wagener MM, Marino IR. Outcome of patients with cirrhosis requiring intensive care unit support: prospective assessment of predictors of mortality. J Gastroenterol 1998; $33: 73-9$. 5 .

Zauner C, Shneeweiss B, Schneider B, Madl C, Klos H, Kranz A, et al. Short-term prognosis in critically ill patients with liver cirrhosis: an evaluation of a new scoring system. Eur $\mathrm{J}$ GastroenterolHepatol. 2000;12:517-22.

6.

Bossali F, Deby G, Atipo-lbara BI, Koumou-Okandzé L, Katendé Kamba S, Loemba E, et al. Probability to survive during two years for people sick of cirrhosis followed up in Pointe-Noire from 2005 to 2014. J Afr Hépatol Gastroentérol. 2015;9:39-43.

7.

Rabe C, Scmitz V, Paashaus M, Musch A, Zickermann H, Dumoulin FL, et al. Does intubation really equal death in cirrhotic patients? Factors influencing outcome in patients with liver cirrhosis requiring mechanical ventilation. Intensive Care Med. 2004;30:1564-71.

8.

Wehler M, Kokoska J, Reulbach U, Hahn EG, Strauss R. Short-term prognosis in critically ill patients with cirrhosis assessed by prognostic scoring systems. Hepatology. 2001;34:255-61.

9.

Lewis TH, Schmidt GA. Acute and chronic hepatic disease. In: Hall JB, Schmidt GA, Wood LDH, editors. Principle of Critical Care. 2nd ed. New York: McGraw-Hill; 1998. pp. 1253-68. 
10.

Yassibanda S, Koffı B, Yangue NC, et al. Les hépatomégalies à l'Hôpital de l'Amitié de Bangui. Mali Médicale. 2004; T 19: 3-4.

11.

Saunders JB, Walters JRF, Davies P, Paton A. A 20 years prospective study of cirrhosis. BMJ. $1981 ; 282: 263-6$.

12.

Karoui S, Hamzaoui S, Sahli F, Matri S, Boubaker J, Filali F. Mortalité au cours des cirrhoses: prévalence, causes et facteurs prédictifs. Tunis Med. 2002;80:21-5.

13.

D’Amico G, Morabito A, Pagliaro L, Marubini E. and the liver study group of "V. Cervello" hospital. Survival and prognostic indicators in compensated and decompensated cirrhosis. Dig Dis Sci. 1986;31:468-75. 14.

Botta F, Giannini E, Romagnoli P, Fasoli A, Malfatti B, Testa R. MELD scoring system is useful for predicting prognosis in patients with liver cirrhosis and is correlated with residual liver function: a European study. GUT. 2003;52:134-9.

15.

Bustamante J, Rimola A, Ventura PJ, Navasa M, Cirera I. Prognostic significance of hepatic encephalopathy in patients with cirrhosis. J Hepatol. 1999;30:890-5.

16.

Gentilini P, Laffi G, La Villa G, Romanelli R, Buzzelli G. Casini- Raggi V. Long course and prognosis factors of virus induced cirrhosis of the liver. Am J Gastroenterol. 1997;92:66-72.

17.

Attia KA, Ackoundou KC, N'dri AT, et al. Child-Pugh-Turcott versus MELD score for predicting survival in a retrospective cohort of black African cirrhotic patients. World J Gastroenterol. 2008;14:286-91. 18.

Cholongitas E, Papatheodoridis G, Vangeli M, Terreni N, Patch D. Systematic review: the model for endstage liver disease - should it replace Child-Pugh's classification for assessing prognosis in cirrhosis? Aliment Pharmacol Ther. 2005;22:1079-89.

19.

Gildea TR, Cook WC, Nelson DR, Aggarwal A, Carey W, Younossi Z, et al. Predictors of a long-term mortality in patients with cirrhosis of liver admitted to a medical ICU. Chest. 2004;126:1598-603.

\section{Tables}

Table 1. General characteristics of patients according to life outcome 


\begin{tabular}{|c|c|c|c|c|}
\hline Variables & $\begin{array}{c}\text { Over all } \\
n=164\end{array}$ & $\begin{array}{c}\text { Survivor } \\
\mathrm{n}=102\end{array}$ & $\begin{array}{c}\text { Death } \\
\mathrm{n}=62\end{array}$ & p \\
\hline Sexe & & & & $<0,001$ \\
\hline Male & $124(75.6)$ & $66(64.7)$ & $58(93.5)$ & \\
\hline Female & $40(24.4)$ & $36(35.3)$ & $4(6.5)$ & \\
\hline Age & $50.1 \pm 16.1$ & $46.9 \pm 16.3$ & $55.5 \pm 14.4$ & 0.001 \\
\hline$<40$ years & $46(28.0)$ & $38(37.3)$ & $8(12.9)$ & \\
\hline $40-59$ years & $60(36.6)$ & $36(35.3)$ & $24(38.7)$ & \\
\hline$\geq 60$ years & $58(35.4)$ & $28(27.5)$ & $30(48.4)$ & \\
\hline \multicolumn{5}{|l|}{ Comorbidités } \\
\hline Prise d'alcool & 108(65.9) & $62(60.8)$ & $46(74.2)$ & 0.055 \\
\hline HBP & $30(18.3)$ & $10(9.8)$ & $20(32.3)$ & $<0.001$ \\
\hline Diabete miltus & $26(15.9)$ & $14(13.7)$ & $12(19.4)$ & 0.229 \\
\hline Etiology of cirrhosis & & & & 0.658 \\
\hline HVB & $90(54.9)$ & $57(55.9)$ & $33(53.2)$ & \\
\hline HVC & $43(26.2)$ & $28(27.5)$ & $15(24.2)$ & \\
\hline HVB-HVC & $31(18.9)$ & 17(16.7) & $14(22.6)$ & \\
\hline \multicolumn{5}{|l|}{ Complications } \\
\hline Ascites & $120(73.2)$ & $66(64.7)$ & $54(87.1)$ & 0.001 \\
\hline Icterus & $96(58.5)$ & $52(51.0)$ & $44(71.0)$ & 0.009 \\
\hline Hepatocarcinoma & $64(39.0)$ & $38(37.3)$ & $26(41.9)$ & 0.003 \\
\hline Gastrointestinal bleeding & $46(28.0)$ & 18(17.6) & $28(45.2)$ & 0.002 \\
\hline Hepatic encephalopathy & $46(28.0)$ & $10(9.8)$ & $36(58.1)$ & $<0.001$ \\
\hline Child Pugh stage & & & & $<0.001$ \\
\hline Class A & $62(37.8)$ & $57(55.9)$ & $5(8.1)$ & \\
\hline Class B & $80(30.5)$ & $34(33.3)$ & $46(25.8)$ & \\
\hline Class C & $52(31.7)$ & 11(10.8) & $41(66.1)$ & \\
\hline
\end{tabular}

Table 2. Biological characteristics of patients according to life outcome

\begin{tabular}{lccccc}
\hline Variables & $\mathrm{n}$ & Over all & Survivor & Death & $\mathrm{p}$ \\
\hline SGPT, UI/l & 124 & $48.0(33.1-161.7)$ & $41.7(24.5-48.0)$ & $165.8(161.7-169.9)$ & 0.491 \\
SGOT, UI/l & 124 & $59.2(32.4-73.3)$ & $63.0(59.2-83.6)$ & $31.9(31.3-32.4)$ & 0.521 \\
Albuminia, mg/dl & 122 & $28.5(4.4-32.5)$ & $4.7(4.1-28.5)$ & $32.5(32.0-33.0)$ & 0.011 \\
BT & 120 & $8.2(2.8-16.2)$ & $3.1(2.4-8.2)$ & $17.4(16.2-18.5)$ & $<0.001$ \\
BD & 120 & $6.6(1.7-8.0)$ & $1.7(1.6-6.6)$ & $8.5(8.0-9.0)$ & $<0.001$ \\
BI & 62 & $8.2(1.5-25.9)$ & $1.6(1.4-43.7)$ & $8.9(8.2-9.5)$ & 0.833 \\
Hb, g/l & 82 & $10.7 \pm 2.4$ & $10.5 \pm 2.2$ & $11.2 \pm 2.8$ & 0.186 \\
ygt & 58 & $437.7(12.5-544.7)$ & $12.5(125.5-651.7)$ & $446.7(437.7-455.6)$ & 0.011 \\
aFP, ng/l & 76 & $10.6(1.8-24.0)$ & $22.0(10.6-26.0)$ & $1.6(1.4-1.8)$ & 0.204 \\
\hline
\end{tabular}

Table 3. Predictors of mortality in multivariate analysis (regression of Cox) 


\begin{tabular}{|c|c|c|}
\hline \multirow[t]{2}{*}{ Factors } & \multicolumn{2}{|c|}{ Adjusted analysis } \\
\hline & $\mathrm{p}$ & aHR $(95 \% \mathrm{CI})$ \\
\hline \multicolumn{3}{|l|}{ HVB } \\
\hline No & & 1 \\
\hline Yes & 0.992 & $1.01(0.33-3.07)$ \\
\hline \multicolumn{3}{|l|}{ HVC } \\
\hline No & & 1 \\
\hline Yes & 0.902 & $1.09(0.29-4.15)$ \\
\hline \multicolumn{3}{|l|}{ Sex } \\
\hline Female & & 1 \\
\hline Male & 0.822 & $1.18(0.28-5.08)$ \\
\hline \multicolumn{3}{|l|}{ Age } \\
\hline$<40$ years & & 1 \\
\hline $40-60$ years & 0.606 & $1.54(0.30-8.00)$ \\
\hline$\geq 60$ years & 0.015 & $2.92(1.98-8.76)$ \\
\hline \multicolumn{3}{|l|}{ Alcoohl } \\
\hline No & & 1 \\
\hline Yes & 0.844 & $1.10(0.43-2.81)$ \\
\hline \multicolumn{3}{|l|}{ BHP } \\
\hline No & & 1 \\
\hline Yes & 0.508 & $1.37(0.54-3.44)$ \\
\hline \multicolumn{3}{|l|}{ Diabete miltus } \\
\hline No & & 1 \\
\hline Yes & 0.219 & $1.80(0.70-4.63)$ \\
\hline \multicolumn{3}{|l|}{ Hepatocarcinoma } \\
\hline No & & 1 \\
\hline Yes & 0.019 & $3.55(1.51-5.85)$ \\
\hline \multicolumn{3}{|c|}{ Gastrointestinal bleeding } \\
\hline No & & 1 \\
\hline Yes & 0.338 & $1.72(0.57-5.19)$ \\
\hline \multicolumn{3}{|c|}{ Hepatic encephalopathy } \\
\hline No & & 1 \\
\hline Yes & 0.002 & $4.64(1.77-12.21)$ \\
\hline \multicolumn{3}{|l|}{ Child Pugh stage } \\
\hline A & & 1 \\
\hline B & 0.017 & 4.93 (1.33-18.30) \\
\hline $\mathrm{C}$ & 0.020 & $4.17(1.25-13.91)$ \\
\hline SGPT* & 0.246 & $1.00(0.99-1.01)$ \\
\hline SGOT* & 0.145 & 1.04 (0.99-1.09) \\
\hline $\mathrm{Hb}^{*}$ & 0.036 & $1.02(1.01-1.04)$ \\
\hline
\end{tabular}

*variable were intdroduced in model as quantitative variable

\section{Figures}




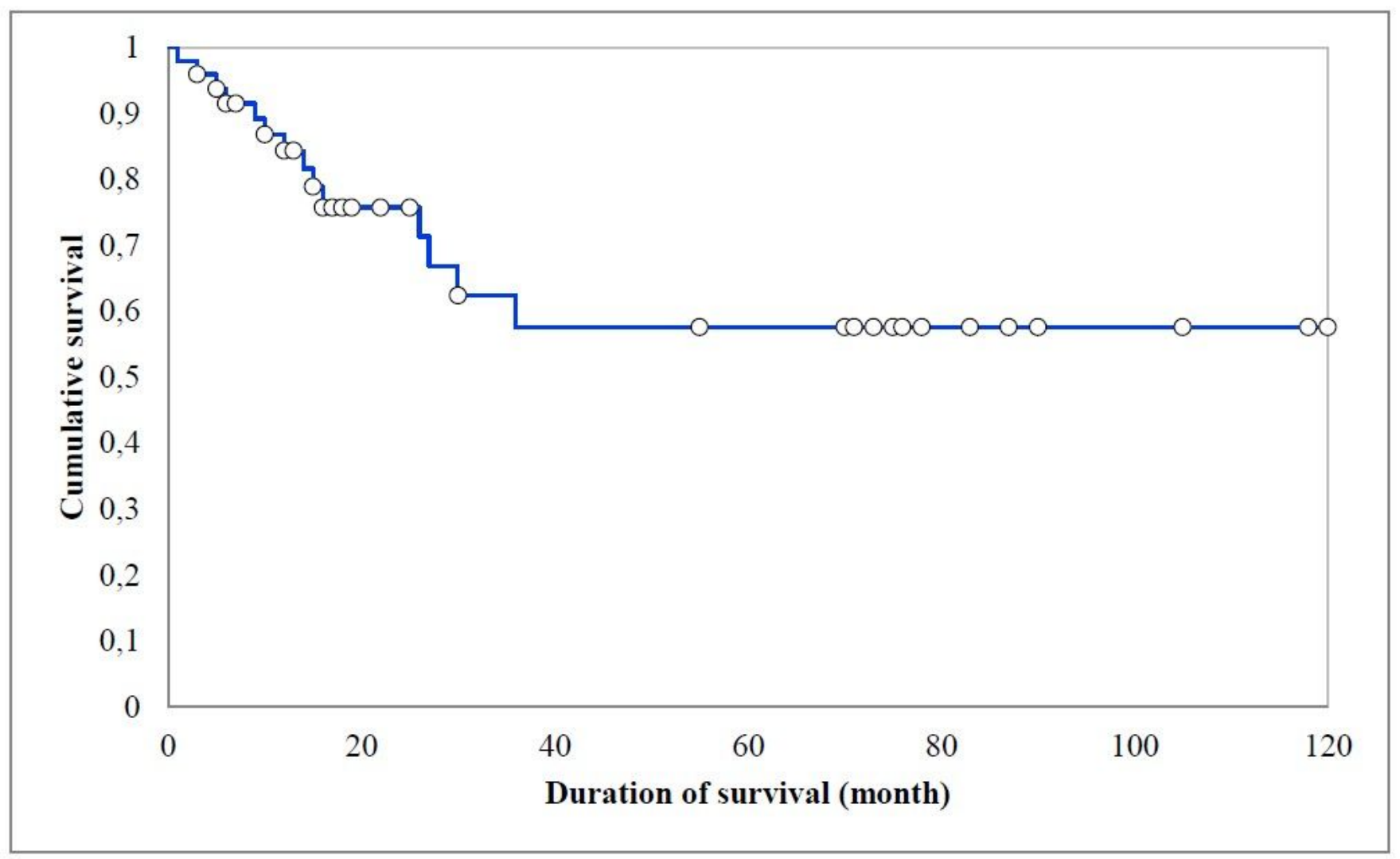

Figure 1

Probability of survival of patients at 10 years of follow-up

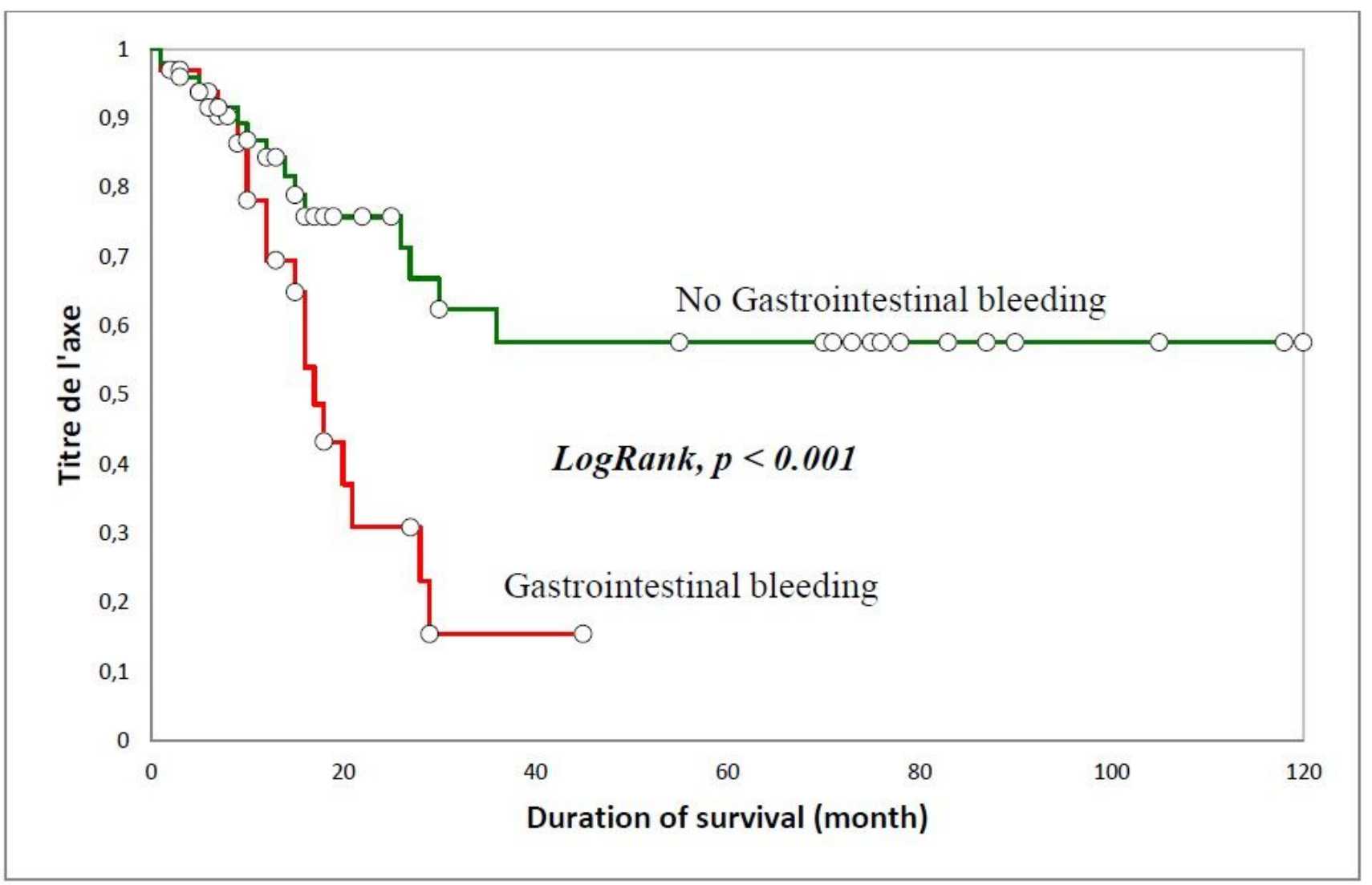


Figure 2

Survival of patients according to Gastrointestinal bleeding

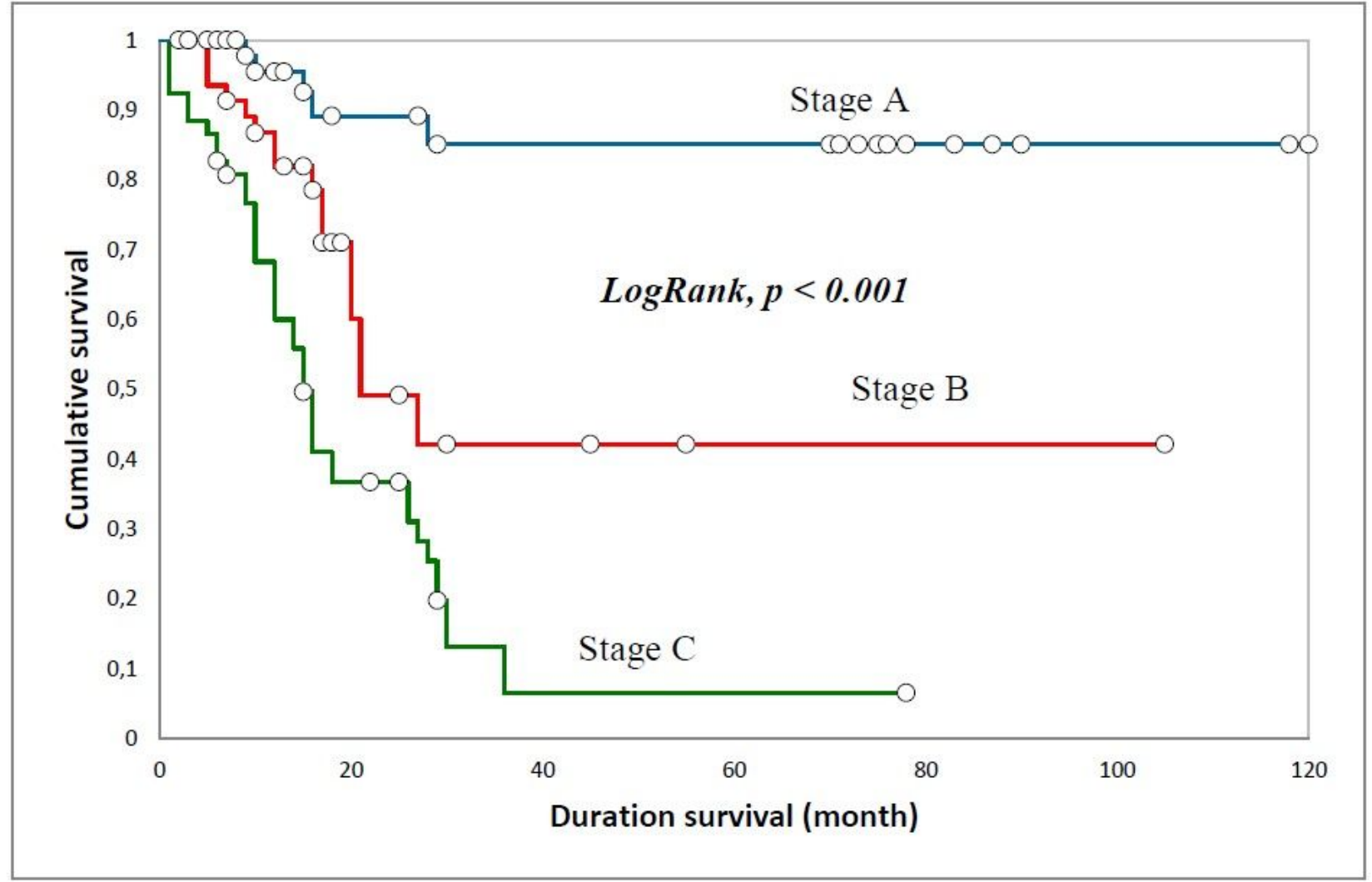

Figure 3

Survival of patients according to Child Pugh stage 


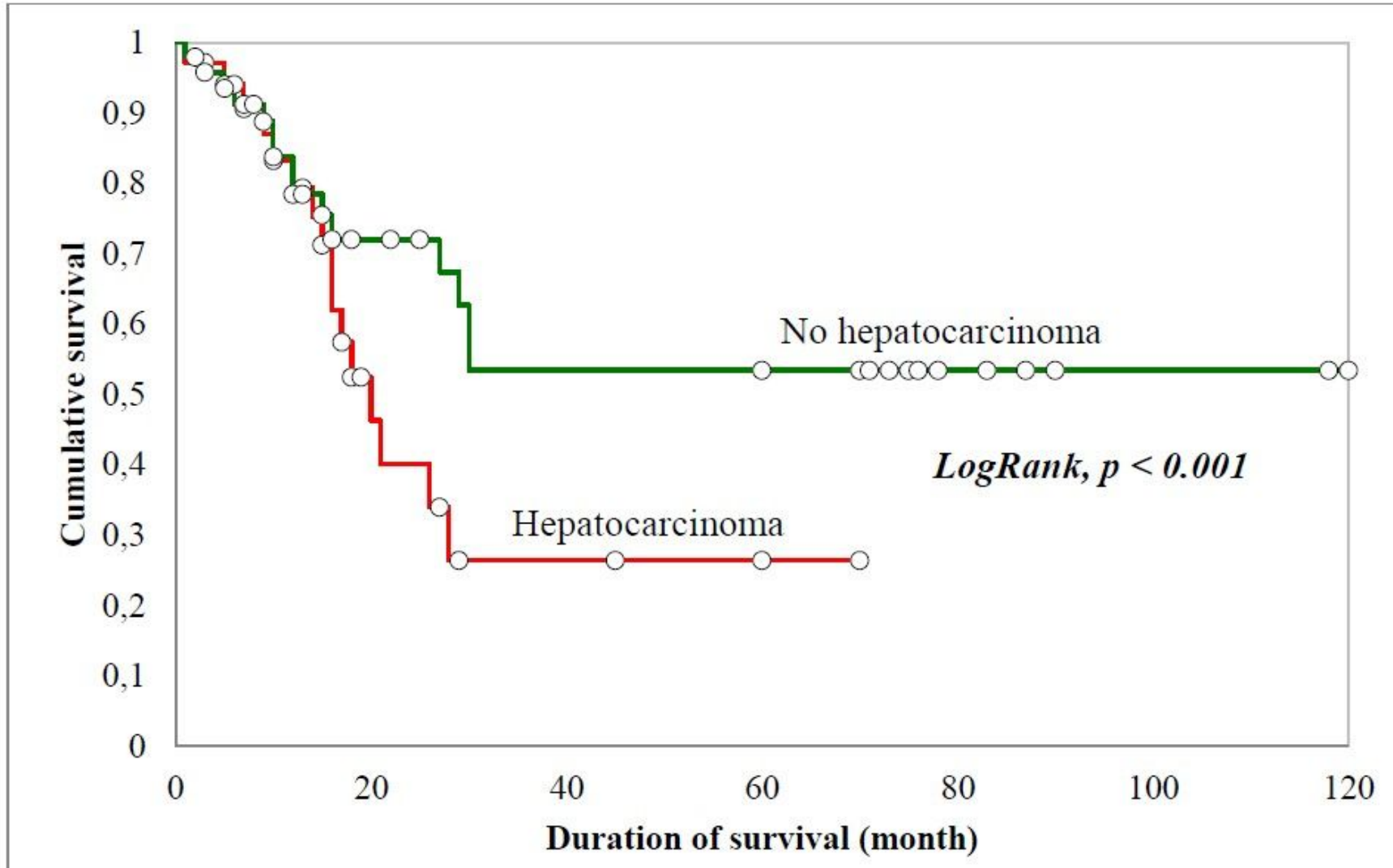

Figure 4

Survival of patients according to hepatocarcinoma 


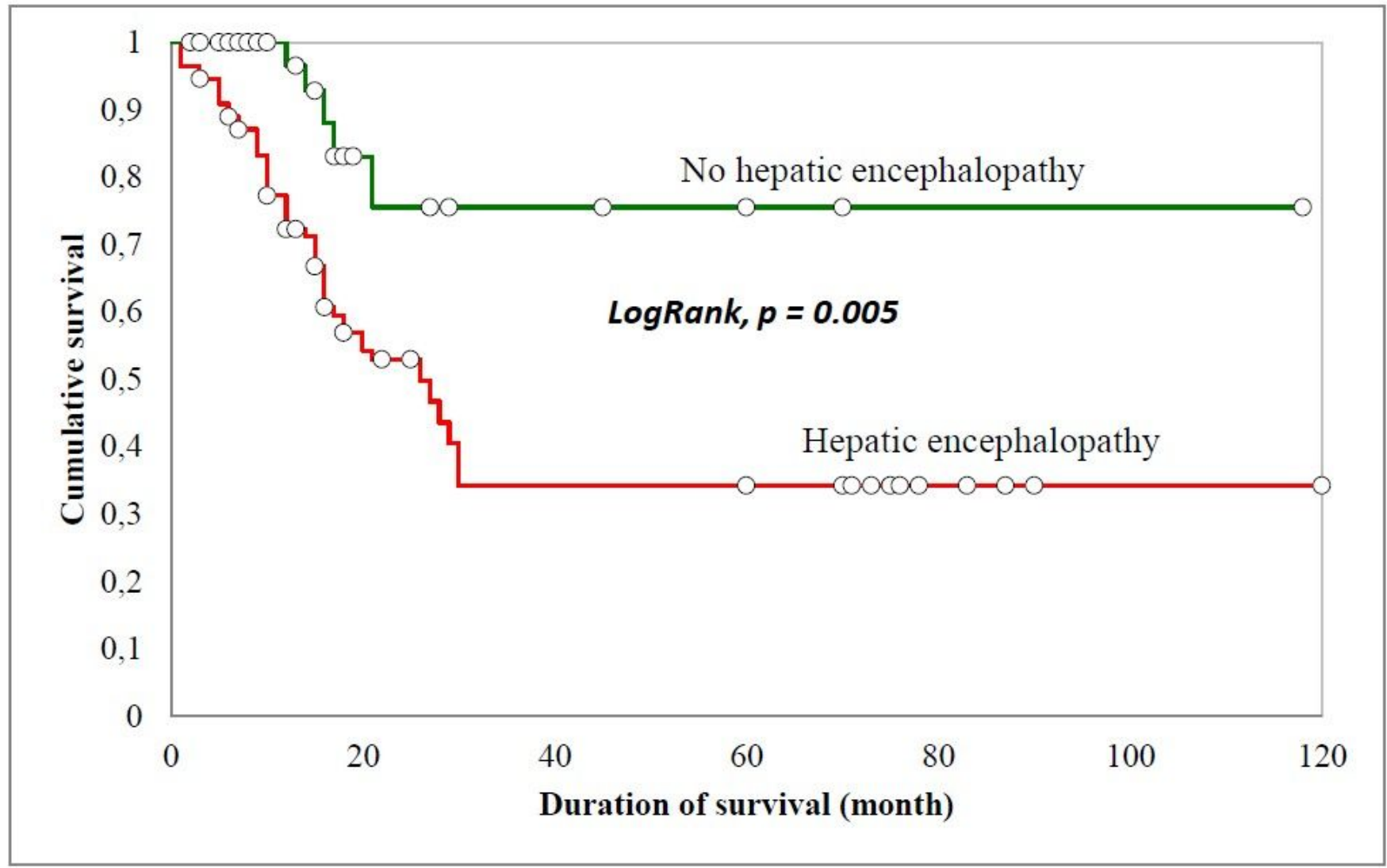

Figure 5

Survival of children according to hepatic encephalopathy 